\title{
DIGITAL IMAGES ON SOCIAL MEDIA AND PROLIFERATION OF FAKE NEWS ON COVID-19 IN KANO, NIGERIA
}

\author{
Mainasara Yakubu Kurfi ${ }^{1}$ (a), Aondover Eric Msughter ${ }^{2}$ (a), Idris Mohamed (b) \\ (a) Bayero University. Kano, Nigeria \\ (b) Usmanu Danfodio University. Sokoto, Nigeria
}

\begin{abstract}
Misinformation becomes rampant in the digital age and social media provide people with the opportunities for engaging more actively in society. The objectives of the study are: (i) to ascertain the extent to which residents of Kano have been exposed to digital images on Covid-19 that often accompany fake news in social media; (ii) to establish the extent to which residents of Kano are influenced by fake news on Covid-19 with images; (iii) to find out the factors that often lead to the influence of fake news with digital images on Covid-19 among social media users in Kano; (iv) to ascertain the social media platforms mostly used in spreading fake news about Covid-19 in the state. Theoretically, Technological Determinism and Perception theories were adopted to analyze these issues. A Positivist approach to data generation and analysis was adopted using the survey method. Two local governments were selected for the study: Tarauni and Kano Municipal. Tarauni local government area had the highest number of the Covid-19 cases, while Kano Municipal had the lowest number. The population of the study consist of 593,087 with a sample size of 400 respondents derived from Taro Yamane's sample size prediction table. The respondents were reached through cluster sampling. A total of 400 copies of questionnaires were administered to respondents in Tarauni and Kano Municipal. However, only 385 copies, which represent (96\%), were retrieved and found usable for the study as the remaining 15 were not returned. The study found that Kano residents were significantly exposed to digital images that often accompany fake news in social media. They read news online every day, prefer news accompanied by images, share and like news online. The study also found that Kano residents are influenced by fake news with digital images on Covid-19 to a very great extent, especially on Facebook. Factors responsible for proliferation of fake news on social media include: perception or instinct, eagerness to be the first to share images and lack of knowledge about image verification tools. The study concludes that ignorance and the old belief that pictures do not lie were responsible for this.
\end{abstract}

Keywords

Covid-19; digital images; fake news; Kano; Nigeria and social media

This work is licensed under a Creative Commons «Attribution» 4.0 International License

1 Email: mykurfi[at]gmail.com

2 Email: aondover7[at]gmail.com 


\title{
ЦИФРОВЫЕ ИЗОБРАЖЕНИЯ В СОЦИАЛЬНЫХ СЕТЯХ И «ДЕЗИНФОРМАЦИИ» О КОВИД-19 В КАНО, НИГЕРИЯ
}

\author{
Курфи Майнасара Якубу ${ }^{1}$ (a), Мсугтер Аондовер Эрик² (a), Мохамед Идрис (b) \\ (a) Университет Байеро. Кано, Нигерия \\ (b) Университет Усману Данфодиё. Сокото, Нигерия
}

\begin{abstract}
Аннотация
В цифровую эпоху дезинформация становится широко распространенной, а социальные сети предоставляют людям возможности для все более активного участия в жизни общества. Цели исследования таковы: 1) уточнить, в какой степени жителей Кано знакомят с цифровыми изображениями, касающимися Covid-19, которые часто сопровождают поддельные новости в социальных сетях; 2) установить, в какой степени поддельные новости, использующие цифровые картинки касательно Covid-19, влияют на жителей Кано; 3) выяснить факторы, которые часто приводят к воздействию поддельных новостей с цифровыми изображениями относительно Covid-19 на пользователей социальных сетей в Кано; 4) выявить те платформы социальных сетей, которые в основном используются для распространения поддельных новостей о Covid-19 в штате. В концептуальном смысле, для анализа этих вопросов были приняты теории технологического детерминизма и восприятия. [В методологическом ключе] был принят позитивистский подход к генерированию и анализу данных с использованием метода анкетирования. Для исследования были выбраны два органа местного самоуправления: Тарауни и муниципалитет Кано. В районе Тарауни было зарегистрировано наибольшее число случаев заболеваний Covid-19, в то время как в муниципалитете Кано было зарегистрировано наименьшее их число. Исследование охватывает 593087 человек с размером выборки 400 респондентов, взятым из таблицы прогнозирования размера выборки Таро Ямане. Респонденты были включены в кластерную выборку. Исследование показало, что жители Кано были в значительной степени подвержены воздействию цифровых изображений, которые часто сопровождают поддельные новости в социальных сетях. Они читают новости в сети каждый день, предпочитают новости, сопровождаемые изображениями, делятся ими и одобряют их. Исследование также показало, что жители Кано в очень большой степени подвержены влиянию поддельных новостей с цифровыми изображениями, посвященными Covid-19, особенно на Facebook. В исследовании делается вывод о том, что ответственность за это лежит на невежестве и устаревшем убеждении, что изображения не лгут.
\end{abstract}

\section{Ключевые слова}

Ковид-19; цифровые изображения; дезинформация; Кано; Нигерия и социальные сети

Это произведение доступно по лицензии Creative Commons «Attribution» («Атрибуция») 4.0 Всемирная

1 Email: mykurfi[at]gmail.com

2 Email: aondover7[at]gmail.com 


\section{INTRODUCTION}

According to a report from the Center for Countering Digital Hate (2020) fake news is one of the trending words not only in the field of communication but across other professions. Hundreds of posts spreading misinformation about Covid-19 are being published online. According to the report, 649 posts were reported on Facebook and Twitter, including false cures, anti-vaccination propaganda and conspiracy theories around 5G. 90\% remained visible online afterwards without any warnings attached. The coronavirus pandemic has forced people to take a step back from daily routines. As people spend more and more time at home, they increasingly rely on the internet, working remotely or video calling on relatives and friends. During this time of uncertainty, like the Covid-19 period, people's engagement with information that is trustworthy is more important than ever. Fake news represents a disturbing media dilemma in the $21^{\text {st }}$ Century.

Nigeria, like every other country in the world, suffers from the spread of fake news. This is evident in the increase in its prevalence in the lexicon and practice in society. Fake news do not exist in texts alone. Images often accompany fake news so as to enhance their believability (Osuagwu, 2020). Also, fake news and hate speeches are not mutually exclusive. Madden (2017) states that the anonymity of online spaces, the attempt to create humour and the habit of internet trolling (hate speech) often contributes to fake news or hoaxes. Furthermore, Mohammed (2017) notes that both hate speech and fake news thrive on repetition and circulation on social media. Mohammed (2017) states that hate speech, disinformation and fake news have something in common. He describes them as a looming danger because they are all capable of destabilising and inciting people to violence and weakening the people's confidence.

Technological developments in the field of internet impact the large group of people that uses this media source to obtain health information. Social media is such a new development that drastically changes websites from a static source to a many-to-many communication channel. The use of informative communication technology, through social media especially, has transcended the use of words only to the creation of false images on Covid-19. Many users of social networking sites do so without regard to the issues of decency, decorum or ethical consideration (Msughter, 2020). One significant effect of this development is that Nigerian citizens can scarcely avoid noticing the presence of these digital images. The images are such a ubiquitous and unavoidable part of the networked social environment of coronavirus campaign on the Internet that forces people to become if not producers or distributors, then at least consumers of these digital images (2020). 
In Northern Nigeria, distrust jeopardizes the response to coronavirus. On April 11, 2020, exactly one month after World Health Organisation (WHO) declared Covid-19 pandemic, Kano State confirmed its first positive Covid-19 case. In the same month, the state witnessed what was described as mysterious deaths, claiming hundreds of lives including the Emir of Rano and seven Professors from Bayero University, Kano ("BUK VC Not Positive, Says Kano," 2020).

Hajara Ibrahim alias Umma, 47, is a mourning mother of five who lost her husband amidst the mysterious deaths in Hotoro, Nassarawa local government of Kano State. According to the report by Nigeria Health Watch (2020) initially, Umma did not believe that Covid-19 was real. "Haven't you heard what the scholars said?" asked Umma, in a regretful tone, as she referred to a video she watched on her son Abdul's Smartphone. In the video, a bearded man was saying, "Covid-19 is a scam and a grand plot against Muslims". Abdul said he got the video from a WhatsApp group to which he belonged (Nigeria Health Watch, 2020).

In a state like Kano, which was once the epicentre of the disease in Northern Nigeria, the risks of fake news and misinformation spreads widely on social media and a majority of the victims could be local community people like Umma, who usually do not even have direct access to this misinformation. Yet, it has shaped their thoughts to develop beliefs like "Covid-19 is a scam"; "Government is using it to generate money", "it will not survive Kano's hot temperature", "it affects and kills only the old", which can make them rebuff Government guidelines for preventing spread of the virus.

The mysterious deaths in April during the height of the Covid-19 pandemic sparked a flurry of confusion and denial by government officials. As social media narratives began to piece together possible reasons for the spike in deaths, dis- and misinformation were driven by ethno-religious tensions in the state, especially on the health status of individual, preventive measures, vaccine, etc. In this context, it has been difficult to gain a full understanding of the reasons behind the mass deaths in Kano State. To complicate matters, a series of forced relocations of almajiri from Kano, Northern Nigeria back to their states of origin sparked concern about the possible exportation of the coronavirus to other parts of the country ("BUK VC Not Positive, Says Kano," 2020).

Similarly, there was a false report with the image of the chairman of the "State Government Covid-19 Funds Raising Committee", the former Vice Chancellor of Bayero University, Kano, Prof. Muhammad Yahuza Bello where he was said to have been tested positive to Covid-19. The Commissioner for Information, Mallam Mohammed Garba, said in a statement that the report was false. He said, "The fake report was orchestrated to mislead the public, as 
the chairman is not suspected to have contracted the virus, let alone testing positive to the virus" (2020).

As misinformation becomes increasingly rampant in the digital age, social media provides people with the opportunities for engaging more actively in the society; but among its constraints, it amplifies misinformation, which is exacerbated by the algorithms of online platforms that make popular content visible, regardless of whether it is reliable. Their algorithms, in addition, expose users primarily to information that is aligned with what they like and are interested in, which is referred to as the problem of the filter bubble. This has created a knowledge vacuum in the literature, which the study intends to fill up. The meaning and extent of these issues in social media will be further explained below.

\section{PROBLEM STATEMENT}

The most credible way of ascertaining the credibility of a piece of information is by scrutinizing the accompanying images (Elkasrawi, Dengel, Abdelsamad, \& Bukhari, 2016). This reflects the long-held axioms that "seeing is believing" and "a picture is worth a thousand words". However, since progression in digital imaging now permits the manipulation of photographs, videos and even audio recordings, there is no longer the guarantee of the authenticity of such texts, which may have been altered or outright be fake representation of the news stories that they should corroborate. This poses a huge challenge of credibility and trust in channels of communication since relying on them in every sector of society is undermined.

According to Sanni (2018) a significant amount of fake stories being shared online were not written texts but images and memes because people prefer images to words. Besides, some individuals do not even believe the concept of 'fake news.' Consequently, accurate and factual news has at times been misconstrued as fake, while fake and inaccurate news has been accepted as factual news especially when it is backed up by images that seem authentic (Osuagwu, 2020). In Kano State, there have been a plethora of reprisal attacks based on fake news on Covid-19 among residents of Kano, accompanied by images. This has created a gap in the body of knowledge in the existing literature on the subject matter, which the current study aims to fill by exploring the influence of digital images on the propagation of fake news among residents of Kano in 2020. 


\section{OBJECTIVES OF THE STUDY}

(i) To ascertain the extent to which residents of Kano have been exposed to digital images on Covid-19 that often accompany fake news in social media.

(ii) To establish the extent to which residents of Kano are influenced by fake news on Covid-19 with images.

(iii) To find out the factors that often lead to the influence of fake news with digital images on Covid-19 among social media users in Kano.

(iv) To ascertain the social media platforms mostly used in spreading fake news about Covid-19 in the state.

\section{RESEARCH QUESTIONS} the study:

The problem statement informed the following basic tools of inquiry for

(i) To what extent have the residents of Kano been exposed to digital images on Covid-19 that often accompany fake news in social media?

(ii) To what extent have residents of Kano been influenced with fake news on Covid-19 with images?

(iii) What are the factors that often lead to the influence of fake news with digital images on Covid-19 among social media users in Kano?

(iv) Which of the social media platforms is mostly used in spreading fake news with images on Covid-19 in Kano?

\section{THEMATIC LITERATURE REVIEW}

\section{Digital Images}

According to Osuagwu (2020) digital images are two-dimensional images represented in a binary form. They are made of picture elements known as pixel, which is the short form of picture elements, often organised in rectangular forms. They are also made up of vector or graphic images, which are mathematically defined by computer software or programs that range from power point, logos, diagrams and other graphics images for promotional or illustrative purposes. It is a representation of a real image as a set of numbers that can be stored and handled by a digital computer.

The properties of the pixel of an image are brightness and colour. Digital images have some advantages over traditional images because of the ability to convert and transfer images from one medium to another and the ability to change them according to one's needs using photo editing software like Photoshop, Photo paint and the Gimp. Users of these can change the colour, 
brightness, delete unwanted visible objects, move others and merge objects from several images and create new images (2020).

\title{
Digital Images in News
}

The role of images in news has been viewed with mixed feelings. Scholars like McQuail (2011) established that images enhance the credibility of news. He noted that providing access to information or access to the site of crisis, visual images are very important in handling crisis news. They have the power to shape the news and people's perception. It is because of the assumption that pictures are more dependable than words. Sarma and Nandi (2014) argued that the ability of images to convince and validate truth has withered, further hindering the trustworthiness of the digital media. They note that:

\begin{abstract}
Many sophisticated digital technologies and photo-editing software like Adobe Photoshop have made the manipulation of images a fair practice. As a result, digital images are becoming prone to forgeries and hence trust in digital images has been eroded. Digital forgery is now a nightmare to individuals (e.g. fake images of celebrities and public figures), societies (fake images targeting religion or race), journalism, scientific publications (2014, p. 878).
\end{abstract}

Abdulrauf-Salau (2013, p. 199) observed that news in social media is predisposed to false information about individuals and government. He notes thus: "In Nigeria, there has been rumours of false information about deaths and bomb threats circulated through Twitter, which eventually turned out to be hoaxes". Fake images have been used to propagate certain stereotypes like racism, religious and ethnic bigotry, to mention a few. Madden (2017) corroborates that the negative role of digital platforms have aided the dissemination of intentional hoaxes and misinformation. She noted that photos of people far away from the scenes of crisis are posted and even fake profiles of victims are often circulated in social media.

\section{UNDERSTANDING NEWS AND FAKE NEWS}

Asemah (2018) sees news as the account of a timely and unusual event in the society. This definition seems limiting because as observed by Fry (2017) the current digital environment as characterised by proliferating social media have changed the traditional notion of news to an account of an unusual event. McQuail (2011) sees news as the main form in which current information about public events is carried by media of all kinds. Although, it is obvious through the definitions given here that one of the distinctive features of news is currency, the latter definition captures the fact that news is information conveyed on different kinds of media. It suffices to presume that news is information about events that are currently happening or that have happened 
recently. Fry (2017) suggests that the traditional notion of news is doomed, going by the impositions of new media technologies on the news processes, for example the collapse of gatekeepers, or the blurring lines of distinction between news, advertisement and entertainment.

Fry's assumption captures the constantly evolving status of news in this digital age by embodying the concept of participation as a vital factor. News is, therefore, seen as a kind of sharing in a connected (digital) space where news is constructed in words, sounds and images not only on social media sites or blogs but on government-controlled or influenced or non-profit sites. According to Fry (2017), participants in this connected (digital) space include: traditional news organisations, social networking sites, amateur journalists and everyone and everything. Fake news is the deliberate fabrication of information to deceive people with the aim of misleading others into believing falsehood and doubting confirmable actualities (White et al., 2017). A lot of fictitious stories are masquerading as news and it is surprising that people do not understand the phenomenon, its origin and the threat it poses to the society.

Nyhan and Reifler (2015) note the danger of fake news and state that fake news can continue to affect the attitudes of those exposed to long after it has been debunked and withdrawn from the media. Scholars like Spectra ("An Introduction, Fake News," 2017) derided the concept of fake news and argued that if it is fake, then it is not news. Fry (2017) corroborates this and points out that the application of the term "fake" to news is inappropriate because news is a social construct, which already has a lot of economic, social and political biases, as well as medium constraints. However, one can only assess the world through instances of accurate accounts of events. Fry (2017) states that the first step of getting the complexity of news requires people to stop using the term "fake". What is it that is fake? The concept is slippery and not applicable, if news is viewed as a social construction. Riley (2017) suggests that rather than call news fake, it should rather be called "lies and garbage".

Contrary to that, scholars like Fry affirm the existence of fake news and argue that it is an old phenomenon in news as exemplified by the Great Moon Hoax, which was published in the New York Sun, in 1835, and the fake drawings of Spanish official strip-searching American women, which precipitated the Spanish American War. Besides, the effect of false narratives is evident in Kano on the primer of the image of Prof. Muhammad Yahuza Bello, which was on Facebook that make people embrace the existence of fake news regarding Covid-19 in Kano State.

Rubin, et al., (2015) noted that there are three types of fake news, which include, first, serious fabrications, fraudulent reporting evident in both old and new media which use yellow journalism and sensationalism to increase traffic 
for profit. It thrives on falsification, fabrication and exaggeration, just the way people in Kano believed that the figures of Covid-19 in the state are overestimated by the Nigeria Centre for Disease Control (NCDC) (Msughter, 2020). Next is hoaxes, which is large-scale deception being deliberately masqueraded as news in social media or mainstream media and often may be picked up and mistakenly validated by supposedly credible news outlets causing harm to the victim. The last one is humorous fakes, which are playful pieces of information meant for humour. The subtypes of humorous fake news includes satire or news parody, which rely on irony and humour to imitate genuine or credible news sources and news game show, where unusual news pieces are read aloud for listeners to call in and guess, which is real or fake. The awareness of the playful intents by the readers often makes them not to take such humour seriously.

\section{EMPIRICAL REVIEW}

According to Osuagwu (2020), images appear in the media to influence public perception of issues or situations. For instance, images have come to account for public perceptions of beauty through the portrayal of women and girls in the media. Studies like Speno and Aubrey (2018) and Mills (2018) focused on how people are oblivious of the fact that such digitized images are used to alter the appearances of females, resulting in 'adultification' of girls and 'youthification' of women in advertising. Specifically, research into fake news and digital images often has two outcomes. One is that people are unaware of digital manipulations of images and cannot differentiate between real and fake digital images. For example, Skop, et al., (2017) research suggests that people need more awareness through digital literacy because their research found that fake images were more prominent on web and social media than other media like television, print and radio.

Yet, other researchers like Cuihua et al., (Shen et al., 2019) discovered that people are aware of fake digital imagery. They found that intermediary variables like social media experience and general internet skills determined the perception of image credibility. Their research found that people with greater levels of digital imaging experience and general Internet skills were more likely to perceive fake images as less credible than people with less experience or skills. However, in that study, credibility of the source and acceptance were not found to be significant.

Another vein of research, which seems to be generating a lot of interest, is on digital image detection techniques, which teaches people how to decipher fake digital images either via manual detection or electronic devices. For example, Sarma and Nandi (2014) identified two broad approaches for detecting forged images to include active and passive (blind) approaches. The active 
approach relies on 'pre-registration or pre-embedded' information to establish the authenticity of an image. It precedes forgery as the image is shielded from being manipulated or altered. It is also called digital watermarking. In contrast, the passive approach works on the assumption that even if altered images leave no visual traces of forgery, their embedded statistics may be altered. This method, therefore, uses forensic tools to detect the statistics of an image.

As an evolving concept, there is no common parameter for measuring people's awareness of fake digital images. However, the standards of related concepts like image credibility perception have been used. Thus, awareness has been measured in terms of whether people assess the credibility of news stories using the images that accompany them, or making subjects perform image credibility checks to authenticate certain images (Elkasrawi et al., 2016). Therefore, the preceding empirical reviews are relevant to this study as the literature established the gap in the study on digital images on social media and the proliferation of fake news on Covid-19, like the one prevalent among residents of Kano.

\section{THEORETICAL UNDERPINNING}

The study is foreground with two theories: Technological Determinism and Perception theories. Technological Determinism Theory was propounded by Marshal McLuhan in 1964. The theory modified Karl Marx's theory of economic determinism to explain the changes that media, as opposed to economic production, have made in human society (Osuagwu, 2020). It argues that media technologies do not only change the environment, they also modify the messages they communicate. The medium determines the content of communication; it also holds power to control people's perception of the world (Asemah, 2018; Osuagwu, 2018). McLuhan (1964) explains the challenges that media pose to people in the process of shaping their thoughts and perceptions. He clearly supported his claim by chronicling four stages of the advent of western civilization in tandem with the media communication accessible to include tribal age (the era of oral mode of communication), literate age (age of visual dependence), print age (widespread visual dependence and print) and finally, the electronic age (ICT era, age of cyberspace or information superhighway) (Asak \& Ohiagu, 2013).

McQuail (2011, p. 103) explains the theory thus, "each communication technology has a bias to particular communication forms, contents, and users." As such, there is a relationship between the commanding communication technology of an age and vital characteristics of society. Electronic age corresponds to the emergent information society with all its biases. These biases are judged against their effects on society or suitability on society. Asak 
and Ohiagu (2013, p. 83) noted in the same vein that McLuhan "seems to see the electronic media as mechanistic and capable of eliciting uncontrollable influence on the people and the society."

The theory has been criticised for being a media-centred theory that posits single-factor explanation of social change and direct mechanistic effect from new media technology, ignoring other social and cultural variables. The fact that news media do not exist in isolation is evident in their convergence with older media, therefore, it is inappropriate to speak of an overbearing medium (McQuail, 2011). The theory is also said to be self-opinionated as it lacks empirical backing (Asemah, 2018).

However, despite the preceding criticisms, its applicability to this study is apt. It is believed that new media technologies that have been made possible through the internet have certain distinguishing features from older media and such features have brought social, cultural and economic changes, which in turn have culminated in a new kind of society. In other words, the interactive nature of communication in this age has brought a lot of changes to traditional mass communication, and fake news is one of the features embedded in the use of technology in propagating digital images on Covid-19 in Kano.

\section{PERCEPTION THEORY}

Perception Theory was propounded by Berelson and Steiner in 1964. It explains the complex role of sense organs in people's behavioural responses to issues (Osuagwu, 2020). They argue that humans are endowed with senses (perceptual) organs (as eyes, ears and nose) to help them recognise and process information in the environment, and such organs serve as inputs to the brain for information processing. The exponents see perception as the complex process by which people select, organise and interpret sensory stimulations into a meaningful and coherent picture of the world (Anaeto, Onabajo, \& Osifeso, 2008). Osuagwu (2020) observed that perception is the procedure in which humans interpret the sensory data, which are generated from human's five senses. These definitions have most obviously shown that sensory organs are central to the process of perception.

Perception involves two types of influences, namely structural influence and functional influence. Structural influence is the direct influence on perception as derived from the physical exposure to certain stimuli. While functional influence arises from indirect factors like belief system and other variables that influence exposure and introduce bias (Anaeto et al., 2008). This theory is relevant to this study because the believability of fake digital images has to do with misperceptions that contradict factual beliefs. People see what they prefer to see in images based on the structural and functional influence. 


\section{METHODOLOGY}

In order to achieve the goals of the study design, a positivist approach of data generation and analysis was adopted. Positivist or post-positivist assumptions have represented the traditional form of research and these assumptions dwell more on quantitative research than qualitative research. This worldview is sometimes called the "scientific method" or "doing science research". It is also called "empirical science" and "post-positivism". Positivists or Post-positivists hold a deterministic philosophy in which causes (probably) determine the effects or the outcomes. The problems studied by positivists reflect the need to identify and assess the causes that influence outcomes, such as digital images on social media and the proliferation of fake news on Covid19 in Kano.

To achieve the success of this design, the survey method was employed. Kano consists of 44 local governments. However, two local governments were selected for the study. They include: Tarauni and Kano Municipal local governments. The two local governments were selected because according to the Technical Coordinator, Kano State Task Force on Covid-19, Dr. Tijjani Hussain, Tarauni local government area had the highest number of Covid-19 cases, while Kano Municipal had the lowest number. Therefore, one local government with the highest cases and one local government with the lowest cases informed the choice of the selection to determine the influence of digital images on social media and the proliferation of fake news on Covid-19 in the state. The respondents were reached through cluster, probability sampling method. Cluster sampling was used because of the need to meet the criteria that ranged from education and knowledge of social media, considering the local government with the highest and the lowest cases of the virus.

According to National Bureau of Statistics (2019) the population of Tarauniis $=221,844$ and Kano Municipal is $=371,243$. Therefore, the population of the study is 593,087. A sample size of 400 as derived from Taro Yamane's sample size prediction table was drawn, which is: $\mathrm{n}=\frac{N}{1+N(e) 2}$ where $\mathrm{n}=$ sample size required, $\mathrm{N}=$ number of people in the population, $\mathrm{e}=$ allowable error $(\%)$. Therefore, this formula was explained in this manner: $\mathrm{n}=\frac{593,087}{1+593,087}$ $(0.05)^{2} \mathrm{n}=\frac{593,087593,087}{1+1482.711483 .71} \mathrm{n}=400$ (rounded).Based on the population strength of each local government, 200 respondents were reached in Tarauni and Kano Municipal respectively.

A questionnaire guide was used to collect data from respondents. The questionnaire contained close-ended questions and was administered with the aid of two research assistants. Data gathered from the questionnaire was ana- 
lysed quantitatively. Frequency tables were used to present measurements using the 5-point Likert scale of which the criterion mean or mean cut off point was 3.00. In the tables, the following terms are applied: TVGE (to a very great extent), TGE (to a great extent), TLE (to a little extent), TVLE (to very little extent), TNE (to no extent).Similarly, the codes for the local governments are as follow: Tarauni (TLG) and Kano Municipal (KMLG) while (NOR) represent the number of respondents.

\section{DATA ANALYSIS AND RESULT}

A total of 400 copies of questionnaires were administered to respondents in Tarauni and Kano Municipal local governments. However, only 385 copies, which represent (96\%), were retrieved and found usable for the study as the remaining 15 were not returned. The demographic information shows that majorities of the respondents were aged between twenty-five and thirty years, single, males and had at least a secondary school certificate.

Research Question One: to what extent have the residents of Kano been exposed to digital images on Covid-19 that often accompany fake news in social media?

\begin{tabular}{|c|c|c|c|c|c|c|c|c|}
\hline \multicolumn{9}{|c|}{ Read News Online Everyday } \\
\hline Score & & & & & Total & NoR & Mean & Std \\
\hline TVGE & TGE & TLE & TVE & TNE & & & & \\
\hline TLG (75) & TLG (52) & TLG (31) & TLG (22) & TLG (15) & Total & 385 & 4.53 & 2.12 \\
\hline KMLG (69) & $\begin{array}{l}\text { KMLG } \\
(51)\end{array}$ & $\begin{array}{l}\text { KMLG } \\
(29)\end{array}$ & KMLG (21) & $\begin{array}{l}\text { KMLG } \\
(20)\end{array}$ & Score & & Accepted & \\
\hline Total $=144$ & $\begin{array}{l}\text { Total = } \\
103\end{array}$ & Total $=60$ & Total $=43$ & Total $=35$ & 1747 & & & \\
\hline
\end{tabular}

\begin{tabular}{|c|c|c|c|c|c|c|c|c|}
\hline \multicolumn{9}{|c|}{ Prefer news accompanied by images } \\
\hline TLG (104) & TLG (41) & TLG (28) & TLG (15) & TLG (8) & Total & 385 & 4.77 & 2.18 \\
\hline KMLG (99) & KMLG & $\begin{array}{l}\text { KMLG } \\
(26)\end{array}$ & KMLG (19) & KMLG (7) & Score & & Accepted & \\
\hline \multirow[t]{2}{*}{ Total $=203$} & & & Total $=34$ & Total $=15$ & 1837 & & & \\
\hline & Total $=79$ & Total $=54$ & & & & & & \\
\hline \multicolumn{9}{|c|}{ Share and like news accompanied by digital images } \\
\hline TLG (102) & TLG (44) & TLG (30) & TLG (11) & TLG (9) & Total & 385 & 4.40 & 2.09 \\
\hline KMLG (93) & $\begin{array}{l}\text { KMLG } \\
(42)\end{array}$ & $\begin{array}{l}\text { KMLG } \\
(27)\end{array}$ & KMLG (13) & $\begin{array}{l}\text { KMLG } \\
(14)\end{array}$ & Score & & Accepted & \\
\hline \multirow[t]{2}{*}{ Total $=195$} & & & Total $=24$ & & 1695 & & & \\
\hline & Total $=86$ & Total $=57$ & & Total $=23$ & & & & \\
\hline
\end{tabular}

Table 1: Extent of Exposure of Kano Residents to Digital Images on Covid-19 in Social Media. (Source: field work, 2020) 
The data in Table 1 shows that Kano residents are exposed to digital images that accompany news in social media to a very great extent. Based on the findings, they read online news every day, prefer news that are accompanied by images, share and like news accompanied by digital images. The mean and standard deviation of each item weighted above the mean score of 3 and is acceptable in the study. The implication of the data implies that Kano residents are exposed to digital images on Covid-19 in social media, and this often made them prefer news accompanied by images as well as share and like news online with images.

Research Question Two: to what extent have residents of Kano been influenced with fake news on Covid-19 with images?

\begin{tabular}{|c|c|c|c|c|c|c|c|c|}
\hline \multicolumn{9}{|c|}{ Believe that pictures do not lie } \\
\hline Score & & & & & Total & NoR & Mean & Std \\
\hline TVGE & TGE & TLE & TVE & TNE & & & & \\
\hline TLG (84) & TLG (49) & TLG (36) & TLG (23) & TLG (4) & Total & 385 & 3.98 & 1.99 \\
\hline $\begin{array}{l}\text { KMLG } \\
\text { (75) }\end{array}$ & $\begin{array}{l}\text { KMLG } \\
\text { (46) }\end{array}$ & KMLG (35) & $\begin{array}{l}\text { KMLG } \\
(27)\end{array}$ & KMLG (6) & Score & & Accepted & \\
\hline Total $=159$ & Total $=95$ & Total $=71$ & Total $=50$ & Total $=10$ & 1536 & & & \\
\hline \multicolumn{9}{|c|}{ Compare real pictures with fakes } \\
\hline TLG (4) & TLG (20) & TLG (31) & TLG (50) & TLG (91) & Total & 385 & 2.15 & 1.46 \\
\hline KMLG (2) & $\begin{array}{l}\text { KMLG } \\
(25)\end{array}$ & KMLG (30) & $\begin{array}{l}\text { KMLG } \\
(48)\end{array}$ & KMLG (84) & Score & & Rejected & \\
\hline Total $=6$ & Total $=45$ & Total $=61$ & Total $=98$ & Total = 175 & 830 & & & \\
\hline \multicolumn{9}{|c|}{ Verify the sources of the images before sharing } \\
\hline TLG (3) & TLG (5) & TLG (10) & TLG (73) & TLG (105) & Total & 385 & 1.85 & 1.36 \\
\hline KMLG (2) & KMLG (3) & KMLG (17) & $\begin{array}{l}\text { KMLG } \\
(66)\end{array}$ & KMLG (101) & Score & & Rejected & \\
\hline Total $=5$ & Total $=8$ & Total $=27$ & $\begin{array}{l}\text { Total } \\
139\end{array}$ & Total $=206$ & 715 & & & \\
\hline
\end{tabular}

Table 2: Extent to which the residents of Kano are influenced by fake news on Covid-19 with images (Source: field work, 2020)

The data in Table 2 indicates that Kano residents are influenced by fake news as accompanied by images. Most of the respondents believe that pictures do not lie, they do not compare real images with fake ones and they do not verify the sources of images before sharing. The mean of 3.98 shows this. Furthermore, all the items used in testing awareness were rejected as they 
were found to be below the criterion mean. A majority of the respondents do not compare real pictures with fakes; neither do they verify sources before sharing. This means that they believe that pictures do not lie but lack the ability to compare real pictures with fakes as well as verification of sources of the images before sharing.

Research Question Three: what are the factors that often lead to influence of fake news with digital images on Covid-19 among social media users in Kano?

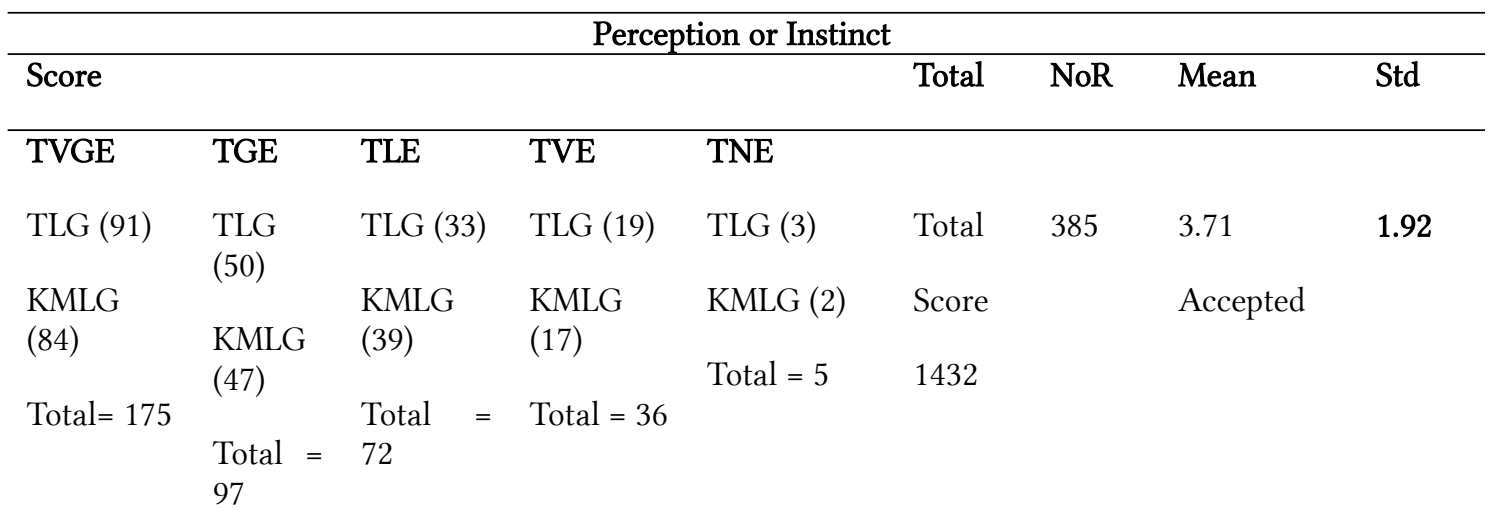

\begin{tabular}{|c|c|c|c|c|c|c|c|c|}
\hline \multicolumn{9}{|c|}{ Eagerness to be the first to share images } \\
\hline TLG (110) & $\begin{array}{l}\text { TLG } \\
(38)\end{array}$ & TLG (26) & TLG (17) & TLG (5) & Total & 385 & 4.54 & 2.13 \\
\hline KMLG & & KMLG & KMLG & KMLG (3) & Score & & Accepted & \\
\hline (107) & $\begin{array}{l}\text { KMLG } \\
\text { (32) }\end{array}$ & & (23) & Total $=8$ & 1749 & & & \\
\hline Total $=217$ & $\underset{70}{\text { Total }}=$ & $\begin{array}{l}\text { Total } \\
50\end{array}$ & Total $=40$ & & & & & \\
\hline
\end{tabular}

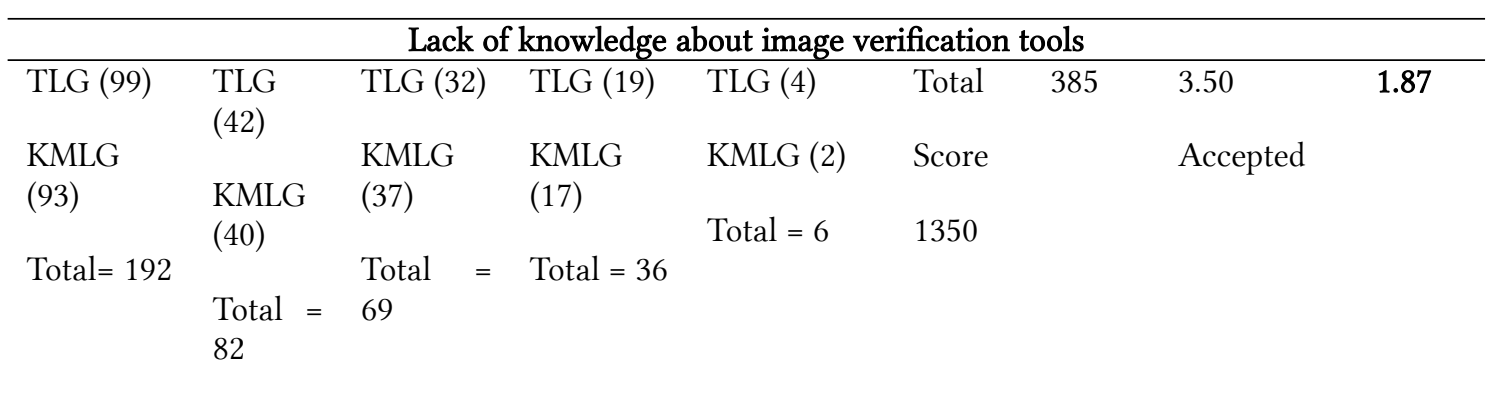

Table 3: Factors that often lead to Influence of Fake News with Digital Images on Covid-19 among Social Media Users in Kano (Source: field work, 2020)

The data in Table 3 shows factors that often make influential the fake news with digital images on Covid-19 among social media users in Kano. All the factors listed were accepted as such factors that make fake news accompanied by images influential. The factors are: eagerness to be the first to share images, which has the highest criterion mean of 4.54, and lack of knowledge 
about image verification tools. This indicates that all the factors lead to increasing the influence of fake news with digital images on Covid-19 among social media users in Kano.

Research Question Four: which of the social media platforms is mostly used in spreading fake news with images onCovid-19 in Kano?

\begin{tabular}{|c|c|c|c|c|c|c|c|c|}
\hline \multicolumn{9}{|c|}{ Facebook } \\
\hline Score & & & & & Total & NoR & Mean & Std \\
\hline TVGE & TGE & TLE & TVE & TNE & & & & \\
\hline TLG (116) & TLG (39) & TLG (27) & TLG (12) & TLG (2) & Total & 385 & 4.63 & 2.15 \\
\hline $\begin{array}{l}\text { KMLG } \\
(112)\end{array}$ & $\begin{array}{l}\text { KMLG } \\
(34)\end{array}$ & $\begin{array}{l}\text { KMLG } \\
(26)\end{array}$ & $\begin{array}{l}\text { KMLG } \\
(14)\end{array}$ & $\begin{array}{l}\text { KMLG } \\
\text { (3) }\end{array}$ & & & Accepted & \\
\hline $\begin{array}{l}\text { Total }= \\
228\end{array}$ & Total $=73$ & Total $=53$ & Total $=26$ & $\begin{array}{l}\text { Total = } \\
5\end{array}$ & 1783 & & & \\
\hline \multicolumn{9}{|c|}{ Twitter } \\
\hline TLG (93) & TLG (57) & TLG (32) & TLG (12) & TLG (2) & Total & 385 & 3.76 & 1.93 \\
\hline $\begin{array}{l}\text { KMLG } \\
(84)\end{array}$ & $\begin{array}{l}\text { KMLG } \\
(55)\end{array}$ & $\begin{array}{l}\text { KMLG } \\
(39)\end{array}$ & KMLG (9) & $\begin{array}{l}\text { KMLG } \\
(2)\end{array}$ & Score & & Accepted & \\
\hline Total $=177$ & $\begin{array}{l}\text { Total }= \\
112\end{array}$ & Total $=71$ & Total $=21$ & $\begin{array}{l}\text { Total }= \\
4\end{array}$ & 1450 & & & \\
\hline \multicolumn{9}{|c|}{ Instagram } \\
\hline TLG (22) & TLG (31) & TLG (35) & TLG (42) & $\begin{array}{l}\text { TLG } \\
(66)\end{array}$ & Total & 385 & 2.22 & 1.48 \\
\hline $\begin{array}{l}\text { KMLG } \\
(29)\end{array}$ & $\begin{array}{l}\text { KMLG } \\
(33)\end{array}$ & $\begin{array}{l}\text { KMLG } \\
(38)\end{array}$ & $\begin{array}{l}\text { KMLG } \\
(41)\end{array}$ & KMLG & Score & & Rejected & \\
\hline Total $=51$ & Total $=64$ & Total $=73$ & Total $=83$ & $\begin{array}{l}(48) \\
\text { Total = } \\
114\end{array}$ & 856 & & & \\
\hline \multicolumn{9}{|c|}{ YouTube } \\
\hline TLG (4) & TLG (17) & TLG (42) & TLG (64) & $\begin{array}{l}\text { TLG } \\
\text { (69) }\end{array}$ & Total & 385 & 1.55 & 1.24 \\
\hline KMLG (9) & $\begin{array}{l}\text { KMLG } \\
(15)\end{array}$ & $\begin{array}{l}\text { KMLG } \\
(39)\end{array}$ & $\begin{array}{l}\text { KMLG } \\
(59)\end{array}$ & KMLG & Score & & Rejected & \\
\hline $10 t a l=13$ & Total $=32$ & Total $=81$ & $\begin{array}{l}\text { Total = } \\
123\end{array}$ & $\begin{array}{l}(67) \\
\text { Total = } \\
136\end{array}$ & 591 & & & \\
\hline
\end{tabular}

Table 4: Social media platforms mostly used in spreading fake news with images on Covid-19 in Kano? (Source: field work, 2020)

The data in Table 4 examines social media platforms that are mostly used in spreading fake news with images on Covid-19 in Kano. The data indicate 
that fake news with images on Covid-19 are often spread mostly on Facebook - to a very great extent, which has the highest criterion mean of 4.63; followed by Twitter with 3.76. Based on the findings, Instagram and YouTube were not used to a great extent in spreading fake news with images on Covid19 in the state. This means that Kano residents often used Facebook to spread fake news with images on Covid-19 in the state.

\section{DISCUSSION OF FINDINGS}

Based on the findings, the study discovered that Kano residents were exposed to digital images that often accompany news in social media to a great extent. They read news online every day, prefer news that is accompanied by images, share and like news online. The findings attest to the fact of the prevalence of fake digital images on Covid-19 within the study period. It demonstrates the influence of prevalent media technology thereby validating the assumption of technology determinism theory. The uncontrollable influence of digital technologies is too overwhelming as observed by Osuagwu (2020). Chedda (2012) notes that a study conducted as far back as 2007 has shown that 350 million photographs were available on Flickr with one million increasing daily, while another one showed that Facebook recorded 50 million total upload of images.

The study also found that Kano residents are influenced by fake news with digital images on Covid-19 to a very great extent. The implication of the findings shows that fake news is proliferating because social media users are not aware of image manipulation devices that enable the propagation of fake images. Mills (2018) found that people are unaware of digital manipulations of images and cannot differentiate between real and fake digital images. Skop et al.'s (2017) research also suggests that people need more awareness through digital literacy because their research found that fake images were more prominent on web and social media than other media like television, print, and radio. Mills (2018) found that people are fed with fake news in both texts and images because of ignorance. The theory of perception also validates the findings in the sense that people are often influenced by what they see or perceive to be right or true.

Similarly, there are factors that often lead to the influence of fake news with digital images on Covid-19 among social media users in Kano. Among these factors are: perception or instinct, eagerness to be the first to share images and lack of knowledge about image verification tools. All the factors used to measure influence and believability in fake digital images were accepted. The findings of the study are in agreement with the findings of Vosoughi et al., (2018) that fake news spread "faster, farther, deeper and more broadly than 
truth". Furthermore, Hollander (2018) suggests that misperception often lead to misinformation or conspiracy beliefs.

Furthermore, data indicate that fake news with images on Covid-19 often spread mostly on Facebook, followed by Twitter. This corresponds with the findings of Msughter (2020) that the outbreak of Covid-19 witnessed a digitalized era of unprecedented campaigns in Nigeria. Citizens are engaged in using social media during the period to sensitize people and to call on the government to help prevent the spread of the virus. Facebook appears to be among the platforms massively used by Nigerians to create awareness on Covid-19 in the country.

\section{CONCLUSION}

The study on the influence of digital images on social media and proliferation of fake news on Covid-19 among residents of Kano, Nigeria, revealed that Kano residents were broadly exposed to digital images that often accompanied news in social media. The study found out that Kano residents are influenced by fake news with digital images on Covid-19 to a very great extent and that there are also factors that often lead to the influence of fake news with digital images on Covid-19 among social media users in Kano. This can be attributed to the deterministic nature of social media, particularly, because of their distinguishing attribute of speed. The study also discovered that Kano residents lack knowledge about image verification tools as well as the negative implication of sharing fake digital images on Covid-19, especially attributing false information on Covid-19 to individuals, using their photographs. The study concludes that ignorance and the old belief that pictures do not lie are responsible for fake news with images on Covid-19 in Kano.

\section{References}

Abdulrauf-Salau, A. (2013). Twitter as News Source to Select Audiences in Ilorin, Nigeria. In D. Wilson (Ed.), Communication and the Media in Nigeria: Social Engagements, Political Development and Public Discourse. African Council for Communication Education.

An Introduction, fake news. (2017). Spectra, the Magazine of the National Communication Association, 53(4), 7.

Anaeto, S. G., Onabajo, O. S., \& Osifeso, J. B. (2008). Models and Theories of Communication. African Renaissance Books Incorporated.

Asak, M. O., \& Ohiagu, O. P. (2013). Digital communication, new media theories and ethics: An introductory text. Uche's Business Service.

Asemah, E. (2018, June 29). Fake news and Nigeria's herder crisis. BBC News. Retrieved from https://www.bbc.com/news/world-africa-44655148 
BUK VC not positive, says Kano. (2020). Retrieved from Punch Newspapers website: https:// punchng.com/buk-vc-not-positive-says-kano/

Chedda, A. (2012, July 4). Feature | Doctored image detection: A brief introduction to digital image forensics. Retrieved January 7, 2021, from Algerian Network for Academics Scientists \& Researchers website: https://www.new.anasr.org/2012/07/04/featuredoctored-image-detection-a-brief-introduction-to-digital-image-forensics/

Elkasrawi, S., Dengel, A., Abdelsamad, A., \& Bukhari, S. S. (2016). What You See is What You Get? Automatic Image Verification for Online News Content. 2016 12th IAPR Workshop on Document Analysis Systems (DAS), 114-119. Santorini, Greece: IEEE. doi: 10.1109/DAS.2016.75

Fears of Covid-19 Outbreak in Nigeria's Kano State. (2020, May 1). Retrieved from Human Rights Watch website: https:/www.hrw.org/news/2020/05/04/fears-covid-19-outbreak-nigerias-kano-state

Fry, K. G. (2017). What Do We Mean by Fake? What Do We Mean by News? Spectra, the Magazine of the National Communication Association, 53(4), 8-12.

Gerding Speno, A., \& Aubrey, J. S. (2018). Sexualization, Youthification, and Adultification: A Content Analysis of Images of Girls and Women in Popular Magazines. Journalism \& Mass Communication Quarterly, 95(3), 625-646. doi: 10.1177/1 077699017728918

Hollander, B. A. (2018). Partisanship, Individual Differences, and News Media Exposure as Predictors of Conspiracy Beliefs. Fournalism \& Mass Communication Quarterly, 95(3), 691-713. doi: 10.1177/1077699017 728919

Madden, S. (2017). Responding to terrorism in the digital age. Spectra, the Magazine of the National Communication Association, 53(3), 20-24.

Mcluhan, M. (1964). The medium is the message. In Understanding Media: The Extensions of Man. McGraw-Hill Education.

McQuail, D. (2011). Mass Communication Theory: An introduction (6. ed., Repr). London: Sage Publication.

Mills, H. L. (2018). Avatar Creation: The Social Construction of "Beauty" in Second Life. fournalism \& Mass Communication Quarterly, 95(3), 607-624. doi: 10.1177/1077699017 722105

Mohammed, L. (2017). Hate speech, disinformation, delivered e-news and national building. A speech delivered at the extra-ordinary meeting the National Council on Information. Jos.

Msughter, A. E. (2020). Internet Meme as a Campaign Tool to the Fight against Covid-19 in Nigeria. Global fournal of Human-Social Science Research, 20(6), 27-39.

National Bureau of Statistics. Kano State population. (2019). Retrieved from https:// www.nigerianstat.gov.ng/

Nyhan, B., \& Reifler, J. (2015). Displacing Misinformation about Events: An Experimental Test of Causal Corrections. Journal of Experimental Political Science, 2(1), 81-93. doi: 10.1017/XPS.2014.22 
Osuagwu, T. R. (2018). Trumped up support for Trump: What did the Nigerian women say? In S. S. Chen, N. Allaire, \& Z. J. Chen (Eds.), Constructing narratives in response to Trump's election: How various population make sense of unexpected victory. Lexington Books.

Osuagwu, T. R. (Ed.). (2020). Influence of digital images on the propagation of fake news among residents of South-east, Nigeria. Fake news and hate speech: Narratives of political instability (6th ed.). Canada: Concord Ontario.

Riley, R. (2017). If it's fake, it's not news. Spectra, the Magazine of the National Communication Association, 53(4), 14-17.

Rubin, V. L., Chen, Y., \& Conroy, N. K. (2015). Deception detection for news: Three types of fakes. Proceedings of the Association for Information Science and Technology, 52(1), 14. doi: $10.1002 /$ pra2.2015.145052010083

Sanni, K. (2018, November 12). Why Nigerians, others fall for fake news-BBC Research | Premium Times Nigeria. Retrieved January 7, 2021, from Premium Times website: https:/www.premiumtimesng.com/news/top-news/295321-why-nigerians-othersfall-for-fake-news-bbc-research.html

Sarma, B., \& Nandi, G. (2014). A Study on Digital Image Forgery Detection. International Journal of Advanced Research in Computer Science and Software Engineering, 4(11), 878-882.

Shen, C., Kasra, M., Pan, W., Bassett, G. A., Malloch, Y., \& O’Brien, J. F. (2019). Fake images: The effects of source, intermediary, and digital media literacy on contextual assessment of image credibility online. New Media \& Society, 21(2), 438-463. doi: $10.1177 / 1461444818799526$

Skop, Y., Smits, L., Seegers, V., \& Yang, W. (2017, October 25). Creating awareness by visualizing the variety of "fake newses." Retrieved from Masters of Media website: http:// mastersofmedia.hum.uva.nl/blog/2017/10/25/creating-awareness-by-visualizing-thevariety-of-fake-newses/

Social media firms fail to act on Covid-19 fake news. (2020, June 3). BBC News. Retrieved from https://www.bbc.com/news/technology-52903680

Vosoughi, S., Roy, D., \& Aral, S. (2018). The spread of true and false news online. Science, 359(6380), 1146-1151. doi: 10.1126/science.aap9559

White, C. J., Carlsen, H., Robertson, A. W., Klein, R. J. T., Lazo, J. K., Kumar, A., ... Zebiak, S. E. (2017). Potential applications of subseasonal-to-seasonal (S2S) predictions: Potential applications of subseasonal-to-seasonal (S2S) predictions. Meteorological Applications, 24(3), 315-325. doi: 10.1002/met.1654

\section{Список литературы}

Abdulrauf-Salau, A. (2013). Twitter as News Source to Select Audiences in Ilorin, Nigeria. In D. Wilson (Ed.), Communication and the Media in Nigeria: Social Engagements, Political Development and Public Discourse. African Council for Communication Education. 
An Introduction, fake news. (2017). Spectra, the Magazine of the National Communication Association, 53(4), 7.

Anaeto, S. G., Onabajo, O. S., \& Osifeso, J. B. (2008). Models and Theories of Communication. African Renaissance Books Incorporated.

Asak, M. O., \& Ohiagu, O. P. (2013). Digital communication, new media theories and ethics: An introductory text. Uche's Business Service.

Asemah, E. (2018, June 29). Fake news and Nigeria's herder crisis. BBC News. Retrieved from https://www.bbc.com/news/world-africa-44655148

BUK VC not positive, says Kano. (2020). Retrieved from Punch Newspapers website: https:// punchng.com/buk-vc-not-positive-says-kano/

Chedda, A. (2012, July 4). Feature | Doctored image detection: A brief introduction to digital image forensics. Retrieved January 7, 2021, from Algerian Network for Academics Scientists \& Researchers website: https:/www.new.anasr.org/2012/07/04/featuredoctored-image-detection-a-brief-introduction-to-digital-image-forensics/

Elkasrawi, S., Dengel, A., Abdelsamad, A., \& Bukhari, S. S. (2016). What You See is What You Get? Automatic Image Verification for Online News Content. 2016 12th IAPR Workshop on Document Analysis Systems (DAS), 114-119. Santorini, Greece: IEEE. doi: 10.1109/DAS.2016.75

Fears of Covid-19 Outbreak in Nigeria's Kano State. (2020, May 1). Retrieved from Human Rights Watch website: https://www.hrw.org/news/2020/05/04/fears-covid-19-outbreak-nigerias-kano-state

Fry, K. G. (2017). What Do We Mean by Fake? What Do We Mean by News? Spectra, the Magazine of the National Communication Association, 53(4), 8-12.

Gerding Speno, A., \& Aubrey, J. S. (2018). Sexualization, Youthification, and Adultification: A Content Analysis of Images of Girls and Women in Popular Magazines. fournalism \& Mass Communication Quarterly, 95(3), 625-646. doi: 10.1177/1 077699017728918

Hollander, B. A. (2018). Partisanship, Individual Differences, and News Media Exposure as Predictors of Conspiracy Beliefs. Fournalism \& Mass Communication Quarterly, 95(3), 691-713. doi: 10.1177/1077699017 728919

Madden, S. (2017). Responding to terrorism in the digital age. Spectra, the Magazine of the National Communication Association, 53(3), 20-24.

Mcluhan, M. (1964). The medium is the message. In Understanding Media: The Extensions of Man. McGraw-Hill Education.

McQuail, D. (2011). Mass Communication Theory: An introduction (6. ed., Repr). London: Sage Publication.

Mills, H. L. (2018). Avatar Creation: The Social Construction of "Beauty" in Second Life. fournalism \& Mass Communication Quarterly, 95(3), 607-624. doi: 10.1177/1077699017 722105

Mohammed, L. (2017). Hate speech, disinformation, delivered e-news and national building. A speech delivered at the extra-ordinary meeting the National Council on Information. Jos. 
Msughter, A. E. (2020). Internet Meme as a Campaign Tool to the Fight against Covid-19 in Nigeria. Global fournal of Human-Social Science Research, 20(6), 27-39.

National Bureau of Statistics. Kano State population. (2019). Retrieved from https:// www.nigerianstat.gov.ng/

Nyhan, B., \& Reifler, J. (2015). Displacing Misinformation about Events: An Experimental Test of Causal Corrections. Fournal of Experimental Political Science, 2(1), 81-93. doi: 10.1017/XPS.2014.22

Osuagwu, T. R. (2018). Trumped up support for Trump: What did the Nigerian women say? In S. S. Chen, N. Allaire, \& Z. J. Chen (Eds.), Constructing narratives in response to Trump's election: How various population make sense of unexpected victory. Lexington Books.

Osuagwu, T. R. (Ed.). (2020). Influence of digital images on the propagation of fake news among residents of South-east, Nigeria. Fake news and hate speech: Narratives of political instability (6th ed.). Canada: Concord Ontario.

Riley, R. (2017). If it's fake, it's not news. Spectra, the Magazine of the National Communication Association, 53(4), 14-17.

Rubin, V. L., Chen, Y., \& Conroy, N. K. (2015). Deception detection for news: Three types of fakes. Proceedings of the Association for Information Science and Technology, 52(1), 14. doi: 10.1002/pra2.2015.145052010083

Sanni, K. (2018, November 12). Why Nigerians, others fall for fake news-BBC Research | Premium Times Nigeria. Retrieved January 7, 2021, from Premium Times website: https://www.premiumtimesng.com/news/top-news/295321-why-nigerians-othersfall-for-fake-news-bbc-research.html

Sarma, B., \& Nandi, G. (2014). A Study on Digital Image Forgery Detection. International Journal of Advanced Research in Computer Science and Software Engineering, 4(11), 878-882.

Shen, C., Kasra, M., Pan, W., Bassett, G. A., Malloch, Y., \& O’Brien, J. F. (2019). Fake images: The effects of source, intermediary, and digital media literacy on contextual assessment of image credibility online. New Media \& Society, 21(2), 438-463. doi: $10.1177 / 1461444818799526$

Skop, Y., Smits, L., Seegers, V., \& Yang, W. (2017, October 25). Creating awareness by visualizing the variety of "fake newses." Retrieved from Masters of Media website: http:// mastersofmedia.hum.uva.nl/blog/2017/10/25/creating-awareness-by-visualizing-thevariety-of-fake-newses/

Social media firms fail to act on Covid-19 fake news. (2020, June 3). BBC News. Retrieved from https://www.bbc.com/news/technology-52903680

Vosoughi, S., Roy, D., \& Aral, S. (2018). The spread of true and false news online. Science, 359(6380), 1146-1151. doi: 10.1126/science.aap9559

White, C. J., Carlsen, H., Robertson, A. W., Klein, R. J. T., Lazo, J. K., Kumar, A., ... Zebiak, S. E. (2017). Potential applications of subseasonal-to-seasonal (S2S) predictions: Potential applications of subseasonal-to-seasonal (S2S) predictions. Meteorological Applications, 24(3), 315-325. doi: 10.1002/met.1654 